\title{
RESPON TUTUR SISWA AUTIS TERHADAP TUTUR DIREKTIF GURU DALAM INTERAKSI PEMBELAJARAN DI KELAS
}

\author{
Siti Robiah, Abdul Syukur Ibrahim, dan A hmad R ofi'uddin
}

Universitas Negeri Malang

\begin{abstract}
The aim of this study is to describe the form, function and response strategies from autistic studentson the teachers' directive in the classroom. This study used a case study. The results showed that there are two categories of the students' spoken responses: (1) speech production in the form of assertive, directive, commissive and expressive; and (2) the speech responses are based on the senses including auditory, visual and emotions. In addition, the function of the students' responses is categorized into two: (i) the effect of speech production in terms of complaining, agreeing, asking, stating something, thanking, apologizing, asserting, reporting, mentioning and offering; and (ii) the students' responses as the effect of the teachers' directive speech acts. Furthermore, the students' response strategies are divided into two categories, namely: (i) internal and external factors, and (ii) the delivery of the students' responses.
\end{abstract}

Keywords: teachers' directive, autistic students, students' responses.

\begin{abstract}
Abstrak: Tujuan penelitian ini adalah mendeskripsikan wujud, fungsi, dan strategi respon tutur siswa autis terhadap tutur direktif guru dalam interaksi pembelajaran di kelas. Penelitian ini menggunakan pendekatan kualitatif jenis studi kasus. Hasil penelitian menunjukkan bahwa wujud respon tutur siswa memiliki dua kategori, yakni (a) pemroduksian wujud respon tutur meliputi respon asertif, direktif, komisif, dan ekspresif; dan (b) pembagian jenis respon tutur menurut indera yang mengamati, yaitu respon auditif, visual, dan perasa. Fungsi respon tutur siswa ditemukan dalam dua kategori, yaitu (a) fungsi pemroduksian respon meliputi fungsi mengeluh, menyetujui, menanyakan, meminta, menyatakan sesuatu, menunjukkan, mengucapkan terima kasih, meminta maaf, menegaskan, melaporkan, menyebutkan, dan menawarkan; dan (b) pemrosesan terjadinya respon disebabkan oleh sebuah aksi dari guru sehingga menimbulkan reaksi dari siswa.
\end{abstract}

Kata Kunci: respon tutur, tutur direktif, tutur siswa autis, respon tutur siswa.

Teori tindak tutur berfokus pada tindak komunikatif berbentuk ujaran. Habermas (dalam Cummings, 2007:284) menggunakan tindak tutur dalam analisisnya terhadap pragmatik universal. Menurutnya, bahasa melakukan tiga fungsi pragmatik, yaitu fungsi representatif, fungsi ekspresif, dan fungsi interaktif. Ketiganya dalam teori tindakan sosial diselaraskan dengan yang disampaikan Austin dan Searle terhadap konsep tindak tutur yang meliputi tiga tindak, yaitu tindak lokusi, ilokusi, dan perlokusi. Teori tindak tutur menempatkan 
tindak tutur sebagai unit dasar komunikasi bahasa manusia (Schiffrin, 2007:386). Lebih lanjut Cummings (2010:254) mengemukakan bahwa tindak tutur membangun kategori yang kaya akan fenomena pragmatik untuk studi linguistik klinis. Oleh karena itu, dapat dikatakan bahwa tindak tutur merupakan gejala individual yang bersifat psikologis dan keberlangsungan ditentukan oleh kemampuan bahasa penutur dalam menghadapi situasi tertentu. Situasi merupakan bagian dari syarat sebuah tuturan dapat diinterpretasikan untuk tujuan tertentu. Dalam tindak tutur lebih dilihat pada makna atau arti tindakan dalam tuturannya sehingga peran tindak tutur dalam keberlangsungan proses komunikasi merupakan unsur yang penting dan utama.

Komunikasi mengacu pada tindakan seseorang atau lebih, yang mengirim dan menerima pesan secara distorsi-terjadi dalam suatu konteks tertentu-mempunyai pengaruh tertentu dan ada kesempatan untuk melakukan umpan balik. Teori komunikasi yang menekankan model S-R ini menunjukkan komunikasi sebagai suatu "aksi-reaksi" atau "stimulus-respon" yang sangat sederhana. Model S-R mengasumsikan bahwa kata-kata verbal, isyarat nonverbal, gambar, dan tindakan-tindakan tertentu akan merangsang orang lain memberikan respon dengan cara tertentu (Mulyana, 2009:39). Teori Stimulus-Respon ini berawal dari hasil eksperimen Ivan P. Pavlov (Chaer, 2003:84), seorang ahli fisiologi Rusia, terhadap seekor anjing percobaannya. Melalui percobaannya tersebut kaitannya dengan pembelajarandisimpulkan bahwa pembelajaran merupakan rangkaian panjang dari respons-respons yang dibiasakan. Menurut teori ini kemampuan seseorang untuk membentuk respons-respons yang dibiasakan berhubungan erat dengan jenis sistem yang digunakan

Dalam kaitan dengan kegiatan belajar dan mengajar yang dilakukan secara tersistem dan terprogram di dalam kelas oleh guru sebenarnya dapat saja diketahui tingkat keberhasilannya dari proses komunikasi yang terjalin. Percakapan dalam proses pembelajaran di kelas merupakan salah satu realitas komunikasi penggunaan bahasa. Kemampuan guru berinteraksi dengan siswanya memegang peranan penting bagi keberhasilan pembelajaran. Sementara di Indonesia ini ada dua jenis sekolah, yaitu sekolah umum dan khusus. Hal ini menuntut guru untuk lebih kreatif, khususnya pada sekolahsekolah khusus, seperti Sekolah Luar Biasa, Sekolah Inklusi, Sekolah Autis, Sekolah Tunarungu, dan sekolah khusus lainnya. Berdasarkan data Kementrian Sosial RI tahun 2008, total anak berkebutuhan khusus (ABK) 1.544.184 anak, dan diprediksikan bahwa sensus nasional tahun 2010, angka anak-anak berkebutuhan khusus (5-18 tahun) adalah 21,42\% dari jumlah ABK dengan berbagai kekurangan/ kecacatan 330.764 anak. Angka ABK yang sudah mendapatkan layanan pendidikan di sekolah khusus (Sekolah Luar Biasa) dan atau di sekolah inklusi, dari jenjang Taman Kanak-kanan sampai Sekolah Menengah Pertama hanya 85.737 anak (25,92\%). Artinya, ada 245.027 (74,08\%) anak dengan kebutuhan khusus yang belum mendapatkan layanan pendidikan di seluruh Indonesia dengan berbagai jenis kelainan, dan sebagaian besar berada di pedesaan dan pusat-pusat perkotaan (Mudjito, dkk., 2012:12).

Berdasarkan penjabaran di atas, dapat diketahui bahwa kondisi anak cukup beragam. Dalam kenyataan setidaknya terdapat dua jenis anak, yaitu anak normal dan anak yang memerlukan penanganan khusus. Salah satu kategori anak yang memerlukan penanganan khusus adalah autis. Saat ini Indonesia belum memiliki data akurat mengenai jumlah anak autis. Data yang ada baru menjangkau sebagian anak autis. Masih banyak anak autis yang belum terdata, terutama mereka yang bertempat tinggal di pedesaan. Namun demikian, pemerintah tetap berusaha memberikan pelayanan pendidikan kepada mereka, di antaranya 
melalui pendirian Sekolah Luar Biasa di sejumlah kabupaten/kota di Indonesia. Dewasa ini, lembaga pendidikan untuk siswa autis yang dikelola swasta juga mulai banyak berdiri di sejumlah kabupaten/kota di Indonesia.

Prasetyono (2008) menyebutkan autis adalah gangguan perkembangan-khususnya terjadi pada masa anak-anak-yang membuat seseorang tidak mampu mengadakan interaksi sosial dan seolah-olah hidup dalam dunianya sendiri. Handojo (2003:24) menyebutkan karakteristik autisme dalam gangguan interaksi sosial antara lain tidak responsif, tidak ada senyum sosial, tidak berkomunikasi dengan mata, tampak asyik bila dibiarkan sendiri, tidak melakukan permainan giliran, bermain repetitif (berulang-ulang), tidak menghendaki perubahan-perubahan, berkembangnya rutinitas yang kaku, dan memperlihatkan ketertarikan yang sangat dan tidak fleksibel . Selain itu, anak autis juga mengalami gangguan dalam berkomunikasi. Stone WL, Turnen L, (2005) dalam penelitiannya mengidentifikasi gejala autis sejak dini dapat dilakukan pada bayi usia 0-24 bulan dengan hasil perilaku yang berorientasi sosial awal dan perhatian bersama adalah gangguan yang paling konsisten dijelaskan dalam anak-anak pada pembangunan sosial. Artinya, ia tidak memahami dan memberikan umpan balik dengan tepat sesuai dengan situasi dan kondisi percakapan. Dalam pernyataan tersebut jelas dikatakan bahwa anak autis mempunyai masalah dalam menyampaikan maksud maupun merespon tuturan dari mitra tuturnya.

Berdasarkan penjabaran di atas, peneliti memiliki tujuan untuk mendeskripsikan secara mendalam tentang respon tutur siswa autis terhadap tutur direktif guru dalam interaksi pembelajaran di kelas. Tujuan tersebut dirinci sebagai berikut. Pertama, bagaimana wujud respon tutur siswa autis terhadap tutur direktif guru dalam interaksi pembelajaran di kelas, dengan kajian pemroduksian tindak tutur dan jenis respon tutur. Kedua, bagaimana fungsi respon tutur siswa autis terhadap tutur direktif guru dalam interaksi pembelajaran di kelas, dengan kajian fungsi pemroduksian tindak tutur dengan fungsi khusus dalam kegiatan belajar mengajar dan pemrosesan terjadinya respon. Ketiga, bagaimana strategi respon tutur siswa autis terhadap tutur direktif guru dalam interaksi pembelajaran di kelas, dengan kajian pembentukan respon tutur dan cara penyampaian respon tutur terjadi.

Respon tutur siswa autis menjadi kajian utama dikarenakan peneliti telah melakukan penelitian pada tahun 2012 dengan judul Pola Komunikasi Guru dengan Siswa Autis dengan hasil tutur direktif guru lebih banyak dan beragam dibanding tuturan lainnya (Robiah, 2012). Selain itu, dalam penelitian tersebut, peneliti menjadikan tuturan guru sebagai kajian utama sehingga pada penelitian lanjutan ini peneliti mengambil kajian utama respon tutur siswa terhadap tutur direktif yang dilakukan guru.

\section{METODE}

Berdasarkan masalah yang telah dirumuskan, pendekatan yang digunakan dalam penelitian ini adalah pendekatan kualitatif dengan jenis penelitian studi kasus. Penelitian ini termasuk jenis penelitian pragmatik, khususnya pragmatik klinis. Ada catatan penting dikemukakan oleh Cummings (2012) bahasa penelitian klinis terhadap autisme memiliki misi emansipasi (pemberdayaan) terhadap kelompok individu yang sering dipandang sebagai anggota masyarakat yang "tidak normal". Teknik pengumpulan data yang digunakan penelitian ini adalah (1) observasi; yang meliputi perekaman dan pencatatan lapangan, dan (2) wawancara. Instrumen penelitian ini menggunakan manusia sebagai instrumen utama. Instrumen utama tersebut yaitu peneliti sendiri yang dipandu dengan 
pedoman transkripsi data; pedoman kodifikasi data; dan pedoman analisis, interpretasi, dan inferensi data. Selain itu, digunakan pula instrumen yang mendukung kevalidan data oleh intrumen utama. Instrumen ini diselaraskan dengan teknik pengumpulan data yang digunakan. Instrumen pendukung tersebut yaitu pedoman observasi dan pedoman wawancara. Data berupa tuturan dan perilaku (verbal, isyarat, dan nonverbal lainnya) siswa autis dan guru di SLB Austis Laboratorium Universitas Negeri Malang yang dikumpulkan dalam bentuk audio visual dan ditranskripsikan sesuai dengan pedoman transkripsi data untuk memudahkan proses analisis data yang dilengkapi dengan konteks. Ini sesuai dengan pandangan Gallardo (2002) bahwa data dalam linguistik klinis berbeda dengan linguistik pada umumnya. Sumber data penelitian ini adalah siswa autis dan guru di SLB Autis Laboratorium Universitas Negeri Malang. Siswa autis dalam penelitian ini adalah kelas I yang dikategorikan autis ringan. Pemilihan kelas tersebut ditentukan oleh lembaga yang bersangkutan mengingat keberlangsungan proses kegiatan belajar mengajar agar tetap pada kealamiahannya. Autis ringan ini dapat menerima kehadiran orang lain dalam lingkungannya. Artinya, siswa tidak merasa terganggu dengan proses belajarnya walaupun ada orang baru di sekitarnya mengingat beberapa karakteristik autis yang antisosial. Selain itu, siswa autis di kelas I ini sebelum memasuki sekolah sudah melewati tahap terapi di lembaga lain sehingga keberterimaan kehadiran peneliti tidak menjadi masalah bagi keberlangsungan proses pembelajaran di kelas.

Segmen-segmen tuturan dan perilaku (verbal dan nonverbal) beserta konteks siswa autis dan guru dalam interaksi pembelajaran di kelas ditetapkan sebagai data yang dianalisis dengan model prosedur interaktif Miles \& Huberman (2007) dan model multidisipliner Cummings (2007). Multidisipliner adalah kombinasi yang saling melengkapi antara lingustik dan disiplin-disiplin ilmu lain, seperti psikologi, antropologi, filsafat, kedokteran/klinis, komunikasi, dan lain sebagainya. Model Multidisipliner Cummings diadaptasi sesuai dengan penggunaan teori yang bersifat eklektik dalam penelitian ini dan disesuaikan pula dengan kajian pada setiap fokus penelitian. Kedua model tersebut digunakan untuk memahami fenomena bahasa dari hubungan antardisiplin ilmu yang berperan mengembangkan konsep-konsep dan teori-teori, khususnya pragmatik, yang tidak mungkin dilakukan hanya dengan satu disiplin itu sendiri. Secara umum, perspektif teori yang digunakan dalam menganalisis respon tutur siswa autis terhadap tutur direktif guru dalam interaksi pembelajaran di kelas adalah teori pragmatik.

\section{HASIL DAN BAHASAN}

Respon tutur siswa autis terhadap tutur direktif guru meliputi tiga hal, yaitu (1) wujud respon tutur siswa autis terhadap tutur direktif guru meliputi dua kategori, yaitu pemroduksian respon tutur dan pembagian jenis respon tutur; (2) fungsi respon tutur siswa autis terhadap tutur direktif guru meliputi dua klasifikasi, yaitu fungsi pemroduksian respon tutur dan pemrosesan terjadinya respon; dan (3) strategi respon tutur siswa autis terhadap tutur direktif guru meliputi dua kategori, yaitu pembentukan respon tutur dan penyampaian respon tutur.

\section{Wujud Respon Tutur Siswa Autis terhadap Tutur Direktif Guru}

Wujud respon tutur siswa autis terhadap tutur direktif guru dalam interaksi pembelajaran di kelas meliputi dua hal, yaitu (1) wujud pemroduksian tindak tutur berdasarkan kategori Searle (1969), dan (2) pembagian jenis respon tutur model Sujanto 
(2004). Kajian tentang wujud respon tutur siswa autis terhadap tutur direktif ini dipaparkan berikut.

\section{Pemroduksian Wujud Respon Tutur Siswa Autis terhadap Tutur Direktif Guru}

Berdasarkan fokus penelitian tentang wujud respon tutur siswa autis terhadap tutur direktif guru serta data yang ditemukan di lapangan, pemroduksian respon tutur siswa autis terhadap tutur direktif guru dalam interaksi pembelajaran dalam penelitian ini ditemukan empat wujud, yaitu asertif, direktif, komisif, dan ekspresif. Masing-masing ditemukan dengan motif tutur direktif guru (selanjutnya MTDG) yang berbeda-beda. Berikut kutipan pembahasannya.

Respon tutur asertif siswa autis terhadap tutur direktif guru dalam penelitian ini ditemukan dalam tujuh MTDG, yaitu memperingatkan, menasihati, menyarankan, mengingatkan, meminta, mengarahkan, dan memerintah. Berikut salah satu pembahasannya.

Mengingatkan merupakan suatu tindakan yang dilakukan seseorang saat melihat kenyataan tidak berjalan sesuai dengan yang semestinya dengan harapan orang yang diingatkan tersebut melakukan sesuatu yang diingatkan. Dalam hal ini respon yang disampaikan siswa atas MTDG mengingatkan ditemukan pada percakapan PV/074 tuturan (64) yang disampaikan siswa 3 berikut.

\section{PV/074}

$\begin{array}{ll}\text { G } & : \\ \text { S2 } & : \\ \text { S1 } & : \\ \text { G } & : \\ \text { S2 } & : \\ \text { G }\end{array}$

$$
\text { (meraut pensil S2) }
$$$$
\text { (memegang-megang penghapus dan tepak pensilnya) }
$$$$
\text { (memerhatikan guru dan S2) }
$$

(memberikan pensil yang sudah diraut) (menerima pensil dari guru dan bersiap-siap mengerjakan tugas) "Tulis di sini, jangan dicoret-coret, ayo tulis!" (menunjukkan tempat untuk menulis tugas yang diberikan guru)

(memerhatikan buku tugas)

"Cepat!"

(bersiap mengerjakan tugas)

“Ayo cepat, tulis!” (melihat S2 tidak segera mengerjakan tugas)

Konteks: Siswa sedang memersiapkan tugas masing-masing yang diberikan guru. Pembelajaran dilaksanakan pada pagi hari Pkl. 08.00 WIB.

Motif tutur direktif guru mengingatkan terdapat dalam tuturan (63) disampaikan kepada siswa 3 yang disebabkan oleh terlalu besarnya huruf-huruf yang ditulis siswa 3 pada buku tugasnya. Tuturan tersebut direspon siswa 3 dengan menunjukkan tulisannya kepada guru sesuai dengan yang diperintahkan sebelumnya. Respon tersebut tampak pada tuturan (64). 


\section{Pembagian Jenis Respon Tutur Siswa Autis terhadap Tutur Direktif Guru}

Jenis respon tutur dapat bermacam-macam bergantung pada indikator yang mengukur hal tersebut. Jenis respon tutur siswa autis dalam penelitian ini diukur berdasarkan tanggapan atau respon menurut indera yang mengamati, yaitu respon auditif, visual, dan perasa. Masing-masing ditemukan sesuai dengan hasil analisis data yaitu dengan motif tutur direktif guru yang berbeda-beda. Berikut kutipan pembahasannya.

Respon auditif adalah respon terhadap apa-apa yang telah didengar petutur, baik berupa suara, kekuatan dan lain-lain. Respon auditif siswa autis terhadap tutur direktif guru dalam penelitian ini ditemukan dalam enam MTDG, yaitu mengajak, memperingatkan, menyarankan, mengingatkan, meminta, dan memerintah. Respon tutur atas MTDG mengingatkan dapat diamati pada percakapan PV/074 tuturan (64) yang disampaikan oleh siswa 3 seperti pada kutipan data di atas. Percakapan PV/074 terjadi antara guru dan ketiga siswanya dengan mata pelajaran bahasa Indonesia pada jam pertama. Dalam percakapan tersebut, terdapat tuturan (63) yang disampaikan guru kepada siswa 3 karena pada pembelajaran hari sebelumnya siswa 3 beberapa kali menulis atau menyalin soal dan bacaan dari buku teks dengan bentuk dan ukuran yang terlalu besar sehingga lembaran yang seharusnya cukup untuk menulis sepuluh soal menjadi tidak cukup. Berdasarkan hal itulah guru mengingatkan siswa 3 untuk tidak menulis dengan bentuk dan ukuran yang besar yang tampak pada tuturan (63). Tuturan tersebut direspon siswa 3 dengan respon auditif yang tampak pada tuturan (64). Artinya, respon tersebut serta-merta siswa 3 sampaikan berdasarkan yang ia dengar dari gurunya tanpa jeda untuk melakukan hal lain.

Berdasarkan deskripsi hasil penelitian terkait dengan wujud respon tutur siswa terhadap tutur direktif guru yang telah dipaparkan di atas, diketahui dua hal berikut. Pertama, pemroduksian tindak tutur. Wujud respon tutur yang dihasilkan oleh siswa autis adalah asertif, direktif, komisif, dan ekspresif. Wujud tuturan yang ditemukan pada penelitian ini sama dengan penelitian Robiah (2012) dalam skripsinya terkait bentuk komunikasi siswa autis. Tutur deklaratif tidak muncul dalam tuturan siswa autis. Hal ini dapat dimaklumi bagi siswa autis dan menegaskan bahwa tutur deklaratif didefinisikan sebagai jenis tindak tutur yang bersifat khas, berhasilnya tindak ilokusi ini akan mengakibatkan adanya kesesuaian antara isi proposisi dan realitas di dunia. Penutur deklaratif haruslah seorang yang mempunyai kekuasaan atau wewenang khusus dalam sebuah institusi tertentu. Tindak tutur deklaratif ialah tindak tutur yang dilakukan penutur dengan maksud untuk menciptakan hal (status, keadaan, dan sebagainya) yang baru, misalnya tuturan memutuskan, membatalkan, melarang, mengizinkan, dan mengangkat (Leech, 1993). Melihat kenyataan tersebut, tidak dimungkinkan bagi siswa autis mampu untuk membuat tuturan deklaratif, baik sebagai penutur maupun petutur.

Wujud tutur muncul terbanyak dalam penelitian ini adalah wujud asertif. Hal ini tentu tidak dapat disangsikan karena wujud tutur asertif adalah tuturan yang menjelaskan apa dan bagaimana sesuatu itu sesuai dengan keadaan sebenarnya. Tutur asertif dinyatakan oleh penutur atau petutur jika keduanya mempunyai pendapat yang sama, yakni guru dan siswa. Wujud asertif muncul pada tujuh motif tutur direktif guru yaitu memperingatkan, menasihati, menyarankan, mengingatkan, meminta, mengarahkan, dan memerintah. Hal ini selaras dengan karakteristik anak autis yaitu adanya gangguan pada interaksi sosial dalam bentuk tidak responsif, tidak berkomunikasi dengan mata, tampak asyik bila dibiarkan sendiri, bermain repetitif (berulang-ulang), tidak menghendaki perubahan-perubahan, berkembangnya rutinitas yang kaku, dan memperlihatkan ketertarikan yang sangat dan 
tidak fleksibel (Handojo, 2003). Beberapa bentuk karakter tersebut memberikan nilai penuh terhadap ditemukannya frekuensi tutur asertif adalah yang terbanyak. Siswa autis tidak memberikan respon dengan banyak ragam selain mengikuti perintah atau hal yang diinstruksikan oleh guru.

Keempat wujud tutur yang ditemukan dalam penelitian ini mempunyai frekuensi berbeda pada setiap siswanya. Frekuensi unggul pertama adalah siswa 1, selanjutnya siswa 3, dan siswa 2. Hal ini sesuai dengan tingkat keautisan mereka apabila dilihat dari DSM-IV sebagai pedoman. Seperti telah dideskripsikan pada paparan deskripsi hasil penelitian, siswa 1 memiliki tingkat sosial lebih tinggi dibanding kedua siswa lainnya. Ini memberikan alasan banyaknya frekuensi kemunculannya dalam tuturan atau gilir tutur.

Kedua, pembagian jenis respon tutur menurut indera yang mengamatinya. Jenis respon tutur yang dihasilkan oleh siswa autis adalah respon auditif, visual, dan perasa. Ketiga respon tersebut muncul namun dengan frekuensi berbeda-beda dan berbeda pula pada setiap siswanya. Frekuensi terbanyak adalah jenis respon auditif. Beberapa jenis gangguan pada anak autis menjelaskan bahwa mereka tidak responsif, tidak mampu membaca emosi orang lain, jarang memulai komunikasi, tidak mampu memelihara suatu pembicaraan dua arah, dan lain sebagainya (Handojo, 2003; periksa juga Prasetyono, 2008). Pernyataan tersebut sejalan dengan yang ditemukan pada penelitian ini yaitu respon auditif yang paling banyak.

\section{Fungsi Respon Tutur Siswa Autis terhadap Tutur Direktif Guru}

Fungsi respon tutur siswa autis terhadap tutur direktif guru dalam interaksi pembelajaran di kelas meliputi dua hal, yaitu (1) pemroduksian tindak tutur kategori Searle (1969) yang telah dikhususkan fungsinya oleh Suyono (1991) berdasarkan frekuensi penggunaannya dalam proses belajar mengajar, dan (2) pemrosesan terjadinya respon menurut Sendjaya (2002) dan Mulyana (2009). Kajian tentang fungsi respon tutur siswa autis terhadap tutur direktif ini dipaparkan sebagai berikut.

\section{Fungsi Pemroduksian Respon Tutur Siswa Autis terhadap Tutur Direktif Guru}

Sebuah tuturan yang diketahui wujud tuturnya maka secara langsung dapat diketahui pula fungsi dari tuturan tersebut. Oleh karena itu, berdasarkan hasil analisis data ditemukan empat wujud respon tutur siswa autis terhadap tutur direktif guru, ditemukan pula dua belas fungsi yakni fungsi tutur menurut frekuensi penggunaannya dalam proses belajar mengajar, meliputi fungsi mengeluh, menyetujui, menanyakan, meminta, menyatakan, menunjukkan, mengucapkan terima kasih, meminta maaf, menegaskan, melaporkan, menyebutkan, dan menawarkan. Berikut kutipan pembahasannya.

Pertama, mengeluh merupakan bagian dari bentuk tindak tutur ekspresif yang mempunyai makna untuk mengungkapkan atau mengutarakan sikap psikologis petutur terhadap keadaan tertentu. Respon jenis ini tampak pada tiga MTDG yaitu mengajak, mengingatkan, dan memerintah.

Mengajak merupakan sebuah kata kerja dalam bentuk ajakan kepada petutur dengan harapan adanya respon dari orang yang diajak tersebut. Mengajak merupakan bagian dari tindak tutur direktif. Respon keluhan siswa terhadap MTDG mengajak yang disampaikan guru tampak pada percakapan PI/008 tuturan (61) yang disampaikan siswa 1 berikut. 
PI/008

(60)

(61)

(64) G :

\section{"A yo, Y ogi sekarang belajar matematika!"} "Uh, belajar lagi."

"Ya iya lah. Ambil buku matematikanya!"

(mengambil buku matematika dari tumpukan buku yang ada di mejanya dan menyerahkan ke guru)

(memeriksa buku matematika siswa dan menyiapkan materi yang akan dipelajari)

Konteks: Guru meminta siswa menyiapkan materi pelajaran matematika dengan membuka buku tersebut. Pembelajaran ini adalah mata pelajaran kedua, yang terjadi pada jam 08.35 WIB.

Tuturan (60) disampaikan guru kepada siswa 1 dalam bentuk ajakan agar siswa 1 kembali fokus belajar. Tuturan tersebut direspon oleh siswa 1 yang tampak pada tuturan (61). Respon tersebut mempunyai fungsi mengeluh, yaitu mengungkapkan atau mengutarakan sikap psikologis siswa 1 terhadap keadaan dalam pembelajaran yang sedang berlangsung. Siswa 1 merasa jenuh dengan aktivitas pembelajaran tersebut. Padahal pembelajaran baru akan berjalan pada mata pelajaran kedua yaitu mata pelajaran matematika dan jam istirahat lebih kurang masih 25 menit berjalan. Hal ini disebabkan siswa 1 ingin segera bermain di halaman yang terlihat pada pembelajaran sebelumnya saat ia selesai mengerjakan tugas yang diberikan guru. Siswa 1 berkali-kali melihat keluar jendela untuk melihat taman bermain.

Kedua, menunjukkan merupakan bagian dari fungsi tutur asertif. Fungsi menunjukkan ini disampaikan siswa pada dua MTDG, yaitu menyarankan dan mengingatkan. Fungsi menunjukkan yang disampaikan siswa atas MTDG mengingatkan dapat diamati pada percakapan PV/074 tuturan (64) yang disampaikan oleh siswa 3 seperti pada data sebelumnya. Percakapan tersebut terjadi antara guru dan ketiga siswanya saat mengerjakan tugas masing-masing yang diberikan guru. Guru membimbing dan mengawasi mereka dengan sesekali memberikan pengarahan ketika melihat siswa mengerjakan tugas tidak sesuai dengan perintah yang seharusnya. Hal ini dapat dilihat pada tuturan (63) yaitu guru mengingatkan siswa 3 untuk menulis huruf dengan tidak terlalu besar ukuran dan bentuknya. Guru mengingatkan siswa 3 karena pada pembelajaran sebelumnya siswa 3 sering menulis dan menyalin soal dengan bentuk dan ukuran tulisan yang besar atau tidak proporsional. Tuturan tersebut direspon siswa 3 dengan fungsi menunjukkan bentuk tulisan yang ia tulis pada buku tugasnya kepada guru. Respon ini dapat dilihat pada tuturan (64).

\section{Pemrosesan Terjadinya Respon Tutur Siswa Autis terhadap Tutur Direktif Guru}

Percakapan antara penutur dan petutur adalah bagian dari sebuah wacana komunikasi. Artinya, komunikasi mengacu pada tindakan oleh satu orang atau lebih, yang mengirim dan menerima pesan secara distorsi oleh gangguan, terjadi dalam suatu konteks tertentu, mempunyai pengaruh tertentu, dan ada kesempatan untuk melakukan umpan balik atau respon. Pernyataan tersebut sejalan dengan teori komunikasi yang menekankan model S-R, yaitu model ini menunjukkan komunikasi sebagai suatu "aksi-reaksi" atau "stimulusrespon" yang sangat sederhana. Model S-R mengasumsikan bahwa kata-kata verbal, isyarat nonverbal, gambar dan tindakan-tindakan tertentu akan merangsang orang lain untuk memberikan respon dengan cara tertentu. Hal ini berarti respon terjadi karena adanya 
stimulus atau efek/reaksi akan nampak apabila ada aksi yang telah sampai pada komunikan/petutur. Oleh karena itu, berikut kutipan paparan pemrosesan terjadinya respon tutur siswa autis terhadap tutur direktif guru berdasarkan ditemukannya delapan motif tutur direktif guru pada hasil analisis data. Reaksi respon siswa atas MTDG mengingatkan dapat diamati pada percakapan PV/074 tuturan (64) seperti pada kutipan data di atas.

Terlihat pada tuturan (63) guru mengingatkan siswa 3 untuk menulis dan menyalin soal yang ada pada buku teks dengan ukuran yang tidak terlalu besar (proporsional). Guru mengingatkan siswa 3 karena sudah berkali-kali yang dilakukan siswa 3 saat menulis dan menyalin soal adalah dengan ukuran yang besar sehingga lembaran buku tugasnya cepat habis. Aksi guru mengingatkan tersebut direspon siswa 3 dengan reaksi yang tampak pada tuturan (64) dengan menunjukkan tulisan pada buku tugasnya kepada guru.

Berdasarkan deskripsi temuan penelitian terkait dengan fungsi respon tutur siswa autis terhadap tutur direktif guru yang telah dipaparkan di atas, diketahui dua hal berikut.

Pertama, fungsi pemroduksian respon tutur siswa autis terhadap tutur direktif guru. Fungsi tutur menjadi sebuah entitas dari wujud tutur respon tutur siswa autis terhadap tutur direktif guru. Oleh karena itu, dengan ditemukannya wujud tutur maka fungsi tutur pun diketahui. Fungsi pemroduksian respon tutur yang ditemukan yaitu mengeluh, menyetujui, menanyakan, meminta, menyatakan, menunjukkan, mengucapkan terima kasih, meminta maaf, menegaskan, melaporkan, menyebutkan, dan menawarkan. Fungsi tutur yang ditemukan sangat bervariasi. Hal ini sejalan dengan pendapat Suyono (1991) yang menyebutkan frekuensi fungsi tutur yang ditemukan dalam proses kegiatan belajar mengajar meliputi menyapa, mengundang, memuji, mengucapkan salam, menyanjung atau merayu, menginterupsi, memotong pembicaraan, memohon, meminta, mengharapkan, mengelak, mengritik, menegur, memperingatkan, menyangkal, menyetujui, menolak atau membantah, meyakinkan, melaporkan, memengaruhi, mengingatkan, menegaskan, menasihati, menanyakan, menaruh simpatik, menyatakan belasungkawa, dan meminta maaf.

Variasi fungsi respon tutur yang ditemukan pada masing-masing siswa sangat beragam. Hal ini sesuai dengan tingkat kemampuan komunikasi pada ketiga siswa tersebut yang telah dipaparkan sebelumnya. Kemampuan komunikasi tersebut disebabkan oleh latar belakang dan kekhasan karakter dari masing-masing siswa. Telah ditemukan pada siswa 1 lebih banyak berbicara daripada dua siswa lainnya sehingga fungsi respon tutur yang dihasilkan sangat beragam dari keduanya. Pernyataan ini sesuai kecenderungan siswa 1 yang hiperaktif dan telah melewati terapi keterlambatan bicara. Selanjutnya siswa 2 mempunyai peringkat ketiga artinya lebih sedikit dari kedua siswa lainnya dalam membentuk fungsi respon tutur. Hal ini disebabkan oleh tahapan komunikasi siswa 2 masih rendah, yaitu pada tahap adanya kecenderungan membeo atau mengikuti yang diucapkan orang lain. Artinya, tuturan tersebut tidak digunakan secara fungsional. Dengan demikian, apabila tuturan terjadi di antara dua orang, yaitu guru dan siswa 2, siswa 2 lebih banyak mengikuti instruksi dari guru. Fungsi tutur yang ditemukan pada siswa 2 adalah menyetujui, melaporkan, dan menyebutkan. Kenyataan tersebut sejalan dengan pernyataan Sussman (dalam Yuwono, 2009:71) dan Ginanjar (2008) yaitu perkembangan komunikasi anak autis dipengaruhi oleh beberapa faktor yaitu kemampuan berinteraksi, cara anak berkomunikasi, alasan dibalik komunikasi yang dilakukan anak dan tingkat pemahaman anak. Selanjutnya ia menuliskan bahwa perkembangan berkomunikasi anak autis berkembang melalui empat tahapan, yaitu the own agenda stage, the requester stage, the early communication stage, dan the partner stage. 
Kedua, pemrosesan terjadinya respon tutur siswa autis terhadap tutur direktif guru yang diawali dengan sebuah aksi dari guru maka akan terlihat reaksi dari siswa. Hal ini sesuai dengan pernyataan Sendjaya (2002:520) yaitu respon terjadi karena adanya stimulus atau efek/reaksi akan nampak apabila ada aksi yang telah sampai pada petutur, yaitu siswa. Dalam hal ini, ketiga siswa memberikan semua respon atau reaksi secara bervariasi sesuai dengan konteks yang melatari wacana interaksi pembelajaran di kelas dan kemampuan komunikasi dari masing-msing siswa yang telah didahului dengan aksi dari masing-masing MTDG yang ditemukan.

\section{Strategi Respon Tutur Siswa Autis terhadap Tutur Direktif Guru}

Strategi respon tutur siswa autis terhadap tutur direktif guru dalam interaksi pembelajaran di kelas meliputi dua hal, yaitu (1) pembentukan respon tutur menurut Walgito (1996), dan (2) penyampaian respon tutur kategori Wijana (1996). Kajian tentang strategi respon tutur siswa autis terhadap tutur direktif ini dipaparkan sebagai berikut.

\section{Pembentukan Respon Tutur Siswa Autis terhadap Tutur Direktif Guru}

Respon yang dilakukan seseorang dapat terjadi jika terpenuhi faktor penyebabnya. Sebagaimana dijelaskan di atas yaitu reaksi timbul akibat adanya sebuah aksi. Hal ini perlu diketahui agar individu yang bersangkutan dapat menanggapi dengan baik. Pada proses awalnya individu mengadakan tanggapan tidak hanya dari stimulus yang ditimbulkan oleh keadaan sekitar. Tidak semua stimulus itu mendapat respon individu, sebab individu melakukan stimulus yang ada persesuaian atau yang menarik dirinya untuk melakukan hal tersebut. Dengan demikian, yang akan ditanggapi adalah individu tergantung pada stimulus juga bergantung pada keadaan individu itu sendiri. Artinya, stimulus akan mendapatkan pemilihan dan individu akan bergantung pada 2 faktor, yaitu internal dan eksternal. Oleh karena itu, berikut dijelaskan pembentukan respon tutur siswa autis terhadap tutur direktif didasarkan pada 2 faktor tersebut yang disesuaikan dengan motif tutur direktif guru yang telah ditemukan.

Pertama, faktor internal adalah faktor yang ada dalam diri individu manusia itu sendiri yang berasal dari dua unsur, yakni rohani dan jasmani. Seseorang yang mengadakan tanggapan terhadap stimulus tetap dipengaruhi oleh eksistensi kedua unsur tersebut. Apabila terganggu salah satu unsur saja, maka akan melahirkan hasil tanggapan yang berbeda intensitasnya pada diri individu yang melakukan tanggapan atau akan berbeda responnya tersebut antara satu orang dengan orang lain. Dengan demikian, strategi respon dengan strategi serupa dapat diamati pada MTDG mengingatkan percakapan PV/074 tuturan (64) yang dilakukan oleh siswa 3 seperti pada kutipan data di atas. Tuturan (63) disampaikan guru kepada siswa 3 untuk mengingatkan siswa 3 agar menulis dan menyalin soal atau teks yang ditugaskan oleh guru dengan ukuran yang proporsional sesuai dengan ukuran buku tugasnya. Tuturan ini disampaikan guru kepada siswa 3 karena sudah beberapa kali pada pembelajaran sebelumnya ketika siswa 3 menyalin atau menulis pada buku tugasnya dengan ukuran huruf atau pun angka dengan cukup besar dan tidak proporsional. Tuturan (63) di atas direspon siswa 3 dengan bentuk persetujuan yang tampak pada tuturan (64). Respon ini dipengaruhi oleh faktor internal yaitu perasaan dan keyakinan siswa 3 akan bentuk dan ukuran tulisan yang ditulisnya sudah sesuai dengan yang diperintahkan oleh guru. 
Kedua, faktor eksternal yaitu faktor yang ada pada lingkungan. Faktor ini berupa intensitas dan jenis benda perangsang atau bisa juga disebut dengan faktor stimulus. Faktor psikis berhubungan dengan objek yang menimbulkan stimulus dan stimulus akan mengenai alat indera. Berikut kutipan pembahasannya dari MTDG yang ditemukan.

Strategi respon dilakukan siswa dengan faktor eksternal atas MTDG memperingatkan dapat dijumpai pada percakapan PV/089 tuturan (221) oleh siswa 1 berikut.

PV/089

\begin{tabular}{|c|c|c|}
\hline$(211) \mathrm{S} 2$ & : & “Kapok.” \\
\hline (212) S1 & : & "Ndak kapok." \\
\hline$(213) \mathrm{G}$ & $:$ & "Siapa sing kapok?" \\
\hline$(214) \mathrm{S} 3$ & $:$ & "Yogi." \\
\hline$(215) \mathrm{S} 1$ & $:$ & "Ndak." \\
\hline$(216) \mathrm{S} 3$ & : & “Iyа." \\
\hline$(217) \mathrm{G}$ & $:$ & (memukul meja dengan penggaris) \\
\hline (218) S1 \&S3 & & (terdiam) \\
\hline (219) S1 & $:$ & (berkata-kata pelan sendiri; $n d u m e l$ ) \\
\hline$(220) \mathrm{G}$ & : & "Diam mulutnya! Mau dapat B apa nggak?" \\
\hline (221) S1 & : & “Iya." (tertunduk) \\
\hline$(222) \mathrm{G}$ & $:$ & "Diam mulutnya!" \\
\hline$(223) \mathrm{S} 1$ & : & $\begin{array}{l}\text { (diam dan memerhatikan guru menyiapkan tugasnya dengan } \\
\text { sesekali melihat jendela) }\end{array}$ \\
\hline
\end{tabular}

Konteks: Siswa sedang menyelesaikan tugas masing-masing tetapi siswa 1 sudah selesai dan dikoreksi oleh guru, namun berulang kali siswa 1 melakukan kesalahan dengan tidak memerhatikan yang disarankan guru sehingga kedua siswa lainnya berseloroh. Pembelajaran terjadi pada pagi hari jam 08.45 WIB.

Percakapan di atas terjadi ketika ketiga siswa menyelesaikan tugas yang diberikan guru. Terlihat siswa 1, siswa 2, dan siswa 3 saling melempar tuturan atas nilai yang diterima siswa 1 pada tugas yang dikerjakannya. Siswa 1 mendapat nilai $\mathrm{C}$ sehingga siswa 2 berseloroh yang tampak pada tuturan (211) dan ditimpali oleh siswa 3 pada tuturan (214). Namun, guru tetap memantau dan membimbing ketiga siswanya agar berjalan pada situasi dan kondisi yang terkendali. Terlihat pada tuturan (220) ketika guru memberi peringatan kepada siswa 1 karena ia terus berbicara atau ndumel dengan nilai $\mathrm{C}$ yang didapatnya. Guru memberi peringatan kepada siswa 1 agar ia tidak lepas kendali sehingga menimbulkan kondisi yang tidak diinginkan bagi kedua siswa lainnya, seperti terganggunya proses belajar. Tuturan guru tersebut direspon oleh siswa 1 dengan strategi yang dipengaruhi oleh faktor eksternal yaitu menyatakan persetujuan dari peringatan yang disampaikan guru. Faktor eksternal tersebut berasal dari tuturan guru dengan memberi peringatan kepada siswa 1.

\section{Penyampaian Respon Tutur Siswa Autis terhadap Tutur Direktif Guru}

Strategi penggunaan tindak tutur adalah cara-cara yang digunakan mitra tutur dalam merespon tutur direktif tertentu yang sesuai dengan motif tutur direktifnya. Dalam kaitan 
itu, strategi penyampaian tindak tutur direktif dapat dikatakan sebagai cara-cara dalam merespon fungsi direktif. Dengan demikian, berbagai tuturan yang disampaikan penutur terhadap mitra tutur menggambarkan strategi tertentu. Berdasarkan cara penyampaiannya, tuturan dapat dibedakan menjadi tuturan langsung dan tidak langsung. Artinya, berdasarkan maksud dari tuturan yang terungkap, ada dua cara pengungkapan maksud tuturan, yaitu cara langsung dan cara tidak langsung. Oleh karena itu, berikut dijelaskan strategi respon tutur siswa autis terhadap tutur direktif guru berdasarkan cara penyampaiannya yang disesuaikan dengan motif tutur direktif guru yang muncul dalam hasil analisis data.

Cara penyampaian respon secara langsung adalah cara pengungkapan maksud dengan tuturan langsung. Dengan cara itu, maksud penutur diungkapkan secara eksplisit dan tindak tutur terungkap secara eksplisit dalam tuturan. Strategi respon tutur siswa terhadap MTDG mengingatkan dapat diamati pada percakapan PV/074 tuturan (64) yang disampaikan oleh siswa 3 seperti pada kutipan data di atas. Percakapan tersebut terjadi ketika guru mempersiapkan tugas untuk ketiga siswanya untuk memulai pembelajaran pada pagi hari. Terlihat pada tuturan (63) guru mengingatkan siswa 3 untuk menulis dan menyalin teks dengan ukuran yang kecil (tidak dengan ukuran besar seperti pada pembelajaran sebelumnya). Tuturan tersebut direspon siswa 3 dengan strategi penyampaian secara langsung yang tampak pada tuturan (64) dengan fungsi persetujuan atas tuturan guru sebelumnya dan menunjukkan buku tugasnya untuk membuktikan ukuran tulisan yang ditulisnya sudah dengan ukuran kecil.

Berdasarkan deskripsi temuan penelitian terkait dengan stategi respon tutur siswa terhadap tutur direktif guru yang telah dipaparkan, diketahui dua indikator berikut.

Pertama, strategi pembentukan respon tutur siswa autis terhadap tutur direktif guru dipengaruhi oleh dua faktor, yaitu faktor eksternal dan internal. Siswa 1 mempunyai tingkat keseimbangan yang sesuai di antara dua faktor yang digunakannya dalam merespon tutur direktif guru, lain halnya dengan siswa 2 dan 3. Siswa 2 cenderung lebih memanfaatkan faktor eksternal dua kali lipat dari faktor internal. Siswa 2 memanfaatkan fakor eksternal tersebut dikarenakan ia masih dalam komunikasi tahap terendah dari kedua siswa lainya sehingga ia hanya akan merespon berdasarkan faktor yang datang dari luar dirinya. Sementara siswa 3 lebih memanfaatkan faktor internal dari pada eksternal, walaupun jarak keduanya sangat tipis. Temuan ini dapat dimaklumi karena siswa 1 yang mempunyai karakteristik hiperaktif dan telah melewati terapi keterlambatan bicara dari pada kedua siswa lainnya. Begitu juga dengan siswa 3, ia lebih mengutamakan faktor internal karena tingginya keinginan untuk diapresiasi guru. Hal ini sesuai dengan pendapat Walgito (1996:55) mengenai respon akan dikeluarkan melalui faktor internal dengan salah satu unsur, yaitu perasaan.

Kedua, strategi penyampaian respon tutur siswa autis terhadap tutur direktif guru dilakukan secara langsung. Ketiga siswa menggunakan strategi penyampaian respon yang sama tetapi dengan frekuensi yang berbeda sesuai dengan kemampuan komunikasi masingmasing. Namun demikian, tidak ditemukan penggunaan strategi penyampaian respon tutur secara tidak langsung dikarenakan ketiganya tidak mempunyai kemampuan dalam berkomunikasi untuk mencapai titik tersebut. Hal ini sesuai dengan pendapat Wijana (1996) dan Suparno (2000), mengenai konsep strategi tindak tutur dengan cara tidak langsung adalah cara pengungkapan maksud dengan tuturan tidak langsung. Dengan cara itu, maksud penutur diungkapkan secara implisit dan tindak tutur terungkap secara implisit dalam tuturan sehingga hal ini dapat dimaklumi dengan tidak ditemukannya strategi respon tutur 
secara tidak langsung pada komunikasi atau tutur respon siswa autis terhadap tindak tutur direktif guru.

\section{SIMPULAN}

Dari gambaran umum temuan penelitian di atas, dapat dikemukakan beberapa hal sebagai berikut. Dalam wacana interaksi kelas siswa autis, wujud respon tutur siswa terhadap tutur direktif guru direalisasikan dalam berbagai motif tutur direktif guru dengan mengemban fungsi respon yang berbeda-beda dan diekspresikan melalui strategi bertutur secara langsung. Semakin tinggi kemampuan komunikasi yang dilakukan oleh siswa, maka semakin beragam respon tutur yang dihasilkan, begitu pula sebaliknya. Dengan kata lain, proposisi ilmiah temuan penelitian ini ialah respon tutur siswa autis terhadap tutur direktif guru dalam wacana interaksi pembelajaran di kelas direpresentasikan secara beragam melalui wujud, fungsi, dan strategi yang berbeda-beda berdasarkan pada keragaman konteks yang melatari wacana interaksi kelas tersebut juga karakter khas dan kecenderungan serta kemampuan komunikasi yang dimiliki masing-masing siswa. Siswa autis sudah memiliki kompetensi pragmatik, seperti juga yang terjadi pada temuan de Villers dkk. (2007:297-300).

Berdasarkan hasil penelitian dapat dikemukakan saran-saran kepada pihak-pihak terkait. Pertama, kepada kepala sekolah disarankan agar melakukan koordinasi kepada semua guru guna mengkaji hasil penelitian dan menindak-lanjuti dengan penentuan format pembelajaran yang seharusnya dilakukan agar lebih mengutamakan pengembangan perolehan bahasa siswa autis dalam wacana komunikasi khususnya dalam interaksi pembelajaran klinis di kelas. Kedua, kepada guru di sekolah autis, hasil penelitian ini direkomendasikan sebagai bahan untuk mengembangkan tuturan dalam proses pembelajaran di kelas dan dapat mengembangkan potensi siswa dengan memperkaya wujud dan fungsi tuturan sehingga respon tutur siswa pun dapat beragam sesuai dengan kemampuan komunikasi dari masing-masing siswa akan berkembang. Ketiga, kepada peneliti selanjutnya, hasil penelitian ini disarankan dapat dijadikan landasan untuk penelitian yang serupa dengan subjek \& objek kajian dapat diperluas dan metodologi kajian dapat dikembangkan. Yang selanjutnya perlu dilakukan adalah bagaimana semangat emansipasi terimplementasi dalam desain penelitian. Para peneliti selanjutnya dapat mengikuti penelitian yang sudah dilakukan oleh Adams (2006) dan Zislin dkk. (2002). Subjek penelitian yang "menderita" dari aspek bahasa sebaiknya diteliti dari desain penelitian yang "memihak", misalnya ada intervensi dari pakar ke dalam "dunia" subjek. Dengan intervensi tersebut maka misi dan visi pragmatik klinis dapat dirasakan secara langsung oleh masyarakat, khususnya para penderita autis dan seluruh keluarganya.

\section{DAFTAR RUJUKAN}

Adams, C. 2006. Intervention for Developmental Pragmatic Language Impairements. Aula Abierta. 82: 79-95.

Chaer, A. 2003. Psikolinguistik; Kajian Teoretik. Jakarta: PT Rineka Cipta.

Cummings, L. 2007. Pragmatik; Sebuah Perspektif Multidisipliner. Terjemahan Abd. Syukur Ibrahim dkk. Yogyakarta: Pustaka Pelajar.

Cummings, L. 2010. Pragmatik Klinis; Kajian tentang Penggunaan dan Gangguan Bahasa secara Klinis. Terjemahan Abd. Syukur Ibrahim dkk. Yogyakarta: Pustaka Pelajar. 
Cummings, L. 2012. Establishing Diagnostic Criteria: The Role of Clinical Pragmatics. Lodz Papers in Pragmatics, 8(1): 61-84. DOI: 10.1515/lpp-2012-0005.

de Villiers, J., Stainton, R.J., and Szatmari, P. 2007. Pragmatic Abilities in Autism Spectrum Disorder: A Case Study in Philosophy and the Empirical. Midwest Studies in Philosophy. XXXI: 292-317.

Gallardo, B. 2002. Disciplinary Frontiers: Language Pragmatics and Pathologies. In Hernández Sacristán, C. and Serra Alegre, E. (Eds.), Clinical Linguistics Studies (pp. 129-174). Valencia: Nau Llibres.

Ginanjar, A.S. 2008. Menjadi Orang Tua Istimewa. Jakarta: Dian Rakyat.

Handojo. 2003. Autisme pada Anak. Jakarta: PT Bhuana Ilmu Populer.

Leech, G. 1993. Prinsip-Prinsip Pragmatik.Terjemahan M.D.D. Oka. Jakarta: UI Press.

Miles, M.B \& Huberman. 2007. Analisis Data Kualitatif. Terjemahan Tjeptjep Rohidi. Jakarta: Universitas Indonesia Press.

Mulyana, D. 2009. Ilmu Komunikasi: Suatu Pengantar. Bandung: PT Remaja Rosdakarya.

Prasetyono, D. S. 2008. Serba Serbi Anak Autis. Yogyakarta: DIVA Press.

Robiah, S. 2012. Pola Komunikasi Guru dengan Siswa Autis Kelas IV Sekolah Autisme Laboratorium UM. Skripsi tidak diterbitkan. Malang: Universitas Negeri Malang.

Schiffrin, D. 2007. Ancangan Kajian Wacana. Terjemahan oleh Abd. Syukur Ibrahim dkk. Yogyakarta: Pustaka Pelajar.

Searle, J.R. 1969. Speech Acts: an Essay in the Philosophy of Language. Cambridge: Cambridge University Press.

Sendjaya, S. D. 2002. Teori Komunikasi. Jakarta: Universitas Terbuka Press.

Stone WL, \& Turner L. The Impact of Autism on Child Development. In: Tremblay RE, Barr RG, Peters RDeV, (Eds.), Encyclopedia on Early Childhood Development. Montreal, Quebec: Centre of Excellence for Early Childhood Development; 2005:1-7. (Online), (http://www.child-encyclopedia.com/documents/Stone-TurnerANGxp.pdf), diakses 24 September 2014.

Sujanto, A. 2004. Psikologi Umum. Jakarta: Bumi Aksara.

Suparno. 2000. Budaya Komunikasi yang Terungkap dalam Wacana Bahasa Indonesia. Dalam Bambang Y. Cahyono (Ed.), 2009. Kumpulan Pidato Pengukuhan Guru Besar Universitas Negeri Malang: Bahasa dan Pembelajaran Bahasa (Jilid II). Malang: UM Press.

Suyono. 1991. Panduan Pengajaran Pragmatik. Malang: Yayasan A3.

Walgito, B. 1996. Pengantar Psikologi Umum. Yogyakarta: Universitas Gadjah Mada Press.

Wijana, ID.P. 1996. Dasar-dasar Pragmatik. Yogyakarta: Andi Offset.

Yuwono, J. 2009. Memahami Anak Autistik. Bandung: Alfabeta.

Zislin, J., Kuperman, V., dan Durst, R.2002. The Generation of Psychosis: A Pragmatic Approach. Medical Hypotheses, 58(1): 9-10. 